\title{
College English Writing Instruction for Non-English Majors in Mainland China: The "Output-Driven, Input-Enabled" Hypothesis Perspective
}

\author{
Junhong Ren \\ ${ }^{1}$ North China Electric Power University (Baoding), Hebei Province, China \\ Correspondence: Junhong Ren, School of Foreign Languages, North China Electric Power University, Mailbox \\ 213, No. 689 Huadian Road, Baoding 071003, Hebei Province, China. Tel: 1-571-250-6731. E-mail: \\ rjh1003@126.com
}

Received: May 7, 2017 Accepted: June 6, 2017 Online Published: June 9, 2017

doi: 10.5539/elt.v10n7p150 URL: http://doi.org/10.5539/elt.v10n7p150

\begin{abstract}
College English writing instruction has been a prominent research area in EFL field in mainland China. This paper has continued the focus by exploring a seemingly effective way for college English writing instruction in China--teaching writing based on reading on the basis of the "output-driven, input-enabled" hypothesis. This hypothesis places emphasis on the important role that language output plays in second language acquisition. Under this hypothesis, language output is both the driving power and objective of EFL teaching; language input provides with the language learners the language forms and content essential for output tasks. This hypothesis meets language learners' psychological needs, our social needs and current educational needs. In essence, theoretical considerations on carrying out writing instruction based on this hypothesis are discussed. To construct writing instruction, teachers may teach writing based on reading since reading could provide the learners with meaningful language input, which language learners could take advantage of to accomplish the writing tasks. Requirements for writing instructions in reading classes are then identified and illustrations on how to conduct writing are provided under this new hypothesis.
\end{abstract}

Keywords: college English writing instruction, output-driven, input-enabled hypothesis, teaching writing based on reading

\section{Introduction}

College English writing--an essential component of EFL teaching at universities and colleges, has an important role to play in helping enhance language learners' comprehensive English abilities (Wang, 2000). However, it has been a challenging area in college English teaching for long. How to conduct effective English writing instruction in China has become an issue that researchers and teachers alike have to pay special attention to.

To our relief, college English writing instruction is receiving an increasing amount of attention in the literature on EFL teaching in mainland China. Ever since 1980s, scholars and teachers from the discipline of EFL instruction have struggled to understand English writing teaching and seek for approaches and techniques to improve college English writing instruction in China. The last two decades or so has witnessed an explosion in the study of EFL writing instruction, when many scholars (Wang et al, 2000; Chen, 2001; Cai, 2001; Han, 2001; Yang \& Dong, 2010; Yang \& Han, 2012; Wang, 2014) offered a variety of proposals and methods on how to improve college English writing instruction. One of the most famous approaches in this regard originates in the work of Wang (2000), namely, the length approach, which was proposed in its primary aim to improve Chinese learners' English writing abilities by gradually lengthening the assigned essays. Length approach on English writing has had an enormous, but still controversial, influence on the study of college English writing instruction. Generally, most of the approaches of and methods to college English writing instruction tend to treat writing as an independent course, which unfortunately does not fit our EFL instruction for non-English majors for whom writing is supposed to be taught in intensive reading courses since no compulsory writing course is provided.

A newly developed perspective on college English teaching is the "output-driven, input-enabled" hypothesis proposed by Wen $(2013,2014,2015)$. This theory presents theoretical and methodological orientations on EFL teaching in its primary claim that comprehensible output is both the driving power and learning objective in 
second language acquisition. Under this view, language output is seen as having great effect on learners' linguistic competence. Understanding the comprehensible input language learners are exposed to enables the learners to accomplish the output tasks. This approach has now been introduced to EFL writing instruction for English majors and vocational business English teaching by some scholars in China, yet one important aspect of English writing teaching--college English writing instruction for non-English majors at university level has been relatively unexplored.

The purpose of this article is to explore an alternative to college English writing instruction for non-English majors: teaching writing based on reading under the output-driven, input-enabled hypothesis. Hopefully it will lift our college English writing instruction out of the dilemma it is now in.

This article continues with an overview of the extant literature and research on college English writing instruction. The following section depicts the methodological approach adopted in the article: the output-driven, input-enabled hypothesis, including a brief introduction to this hypothesis, its motivation and features. The last section discusses current college English writing instruction for non-English majors in mainland China and presents ideas on how writing could possibly be taught based on reading under this hypothesis.

\section{Literature Review}

Writing is viewed as a key language skill in EFL teaching (Wang, 2005). The study of college English writing instruction has been a prominent area in the second language field. Generally speaking, researches into college English writing instruction can be found on both macroscopic and microscopic level.

On the microscopic level, many researches discussed effective methods and techniques in writing instruction. Li (1997), Wu (2001), Chen (2001), Dong (2003) and Yang and Dong (2010) advocated combining reading with writing by means of sample writing analysis. Yang (1998) insisted on combining writing with oral English by means of group discussion. Shi (2001), Wang and Gao (2001) claimed that English writing instruction should take advantage of the computer network technology and information technology. Liu, Ge and Li's study (2012) showed that corpus-based model can effectively improve students' writing level which in turn enhances students' English competence. Guo (2009) used blogs to improve teaching of college English writing. Ni (2009) suggested developing students' writing ability via collaborative-learning-based writing in a web environment. Yu (2010) explored writing collaboratively on a wiki. Liu, Zhang and Wang (2014) introduced teaching resource platform supported by information technology to facilitate writing instruction.

On the macroscopic level, researchers have made explorations into varied teaching approaches to college English writing instruction. Some researchers carried out discussions on the merits and demerits of different approaches and how they could be employed in EFL writing classes in China. The most important and influential approach in regard to writing instruction has been proposed by Wang (2000)--the length approach. Wang's approach has influenced many studies in English writing instruction and has had direct empirical support in the field of EFL teaching (Guo, 2011; Wu, 2005; Fang, 2004). Yet in spite of its effectiveness in overcoming the Chinese learners' anxiety in English writing and enhancing the Chinese learners' sense of fulfilment and self-confidence in English learning, it is vulnerable to attack due to the drawbacks in its experiment and research design. For one thing, the experiment designed to validate the approach is of low internal validity. For another, "learning" is not explicitly defined and the procedures for facilitating learning are not specified (Wen, 2005).

Now, researches on writing instruction have pointed to a newly developed EFL teaching hypothesis - the "output driven, input-enabled" hypothesis (the revised version of the former "output-driven" hypothesis put forward in 2008) proposed by Wen $(2013,2014,2015)$. Chen (2010) and Wang (2011) explored reforms in English writing instruction based on output-driven hypothesis. They both indicated the importance of integrating English writing instruction with instruction of other language skills on the way to improving students' comprehensive English abilities and writing abilities in particular. Chen (2010) suggested that English writing teaching be connected with other English courses and last the four academic years for English majors. Wang (2011) probed into English writing teaching and reform of higher vocational business English, pointing out that vocational business writing should be project-based so that language learners can get fully involved in the writing class activities; thereby making sure that output tasks could be accomplished.

As far as the approaches and methods are concerned, most of them tend to take college English writing as an independent course, which unfortunately does not fit our English writing instruction reality for most non-English majors. For one thing, unlike instruction for English majors, no compulsory writing course is offered to non-English majors at most universities in mainland China. As a result, College English writing has to be taught in reading classes, which has given rise to many problems. For another, different from vocational business English writing which centres on practical writing, most English writing classes for university non-English 
majors focuses on academic writing skills training.

Since English writing instruction for non-English majors at university level has been relatively unexplored under the "output-driven, input-enabled" hypothesis, this article attempts to explore a teaching model on the basis of the perspective of this newly developed tentative teaching theory in the hope that language learners can benefit from our English writing instruction.

\section{Output-Driven, Input-Enabled Hypothesis}

"Output-driven, input-enabled" hypothesis is a tentative theory of foreign language teaching for students at tertiary level. Contrary to the traditional teaching ideology that centres on text learning, this hypothesis places emphasis on the importance of language output, or specifically teaching students to do things with English. As a result, whether students can complete the language output tasks upon acquiring the language forms and content of the learning materials has become the standard to assess teaching effectiveness and learning outcome.

This new hypothesis makes two major claims. First, in terms of teaching process, output has more driving force than input in stimulating English learning. It can not only promote students' abilities to use receptive linguistic knowledge they have acquired, but also arouse their desires to generate new linguistic knowledge. Second, in terms of teaching objective, it meets our social needs to put output as our language learning objective. To complete the output tasks, students are required to select one or more of the output skills of speaking, writing and translation essential to the future job market as their learning target(s) and cultivate it/them accordingly.

Under this hypothesis, output is seen as both a driving force and an objective to second language acquisition. In completing the language output tasks, language learners will encounter the gap in their linguistic knowledge, which prompts them to process relevant input materials with more focused attention so that they can learn something new about the language, in terms of both language form and content. In this way, learning can be enhanced through the act of producing language, which increases the likelihood that learners are aware of what they can and cannot do with English, which then leads the learners to reappraise their capabilities in English and stimulate them to acquire new knowledge.

\subsection{Motivation}

First, this new hypothesis meets students' academic and psychological requirements. The first-year students have accumulated sufficient receptive linguistic knowledge before entering college and are likely to develop learning-weariness if they see no changes in English teaching methods. This undesirable situation may be avoided if the English teachers instruct their students to do things with English. It can not only activate the knowledge students have always acquired but also stimulate students' motivation to obtain new knowledge when they are aware that their prior knowledge is insufficient for them to cope with the tasks at hand.

Second, this new hypothesis meets our social demands. Job-takers communicate with one another by means of speaking, writing, interpreting or translating rather than listening and reading. Hence, our students, the future job-takers, may have a hard time doing things with English if they are taught the receptive language skills instead of the productive ones. If they pick up one or more of the productive language skills of speaking, writing, interpreting or translating, however, it will be much easier for them to find their places in the future job market.

Third, this new hypothesis is in line with advances of second language acquisition theories. Krashen's Input Hypothesis gives primary emphasis to the importance of comprehensible input (CI) on the increase of underlying linguistic competence. However, because it fails to acknowledge the significant role that language output plays in language acquisition, this hypothesis has received criticism from some academics. Swain's Output Hypothesis posits that language output has four functions to perform in language acquisition - noticing/triggering function, hypothesis testing function, meta-linguistic function and fluency function. Learning takes place when a learner encounters gaps in his or her linguistic knowledge of the second language. By noticing a gap between what they want to say and what they can say, learners may be prompted to recognize some of their linguistic problems, bringing to their attention something they need to discover about their L2 (Swain, 1995: pp. 125-126). This may trigger cognitive process which might generate linguistic knowledge that is new for learners, or which consolidates their existing knowledge (Swain \& Lapkin, 1995). Socio-cultural perspective on SLA holds that language learning should not be separated from language use. Wen's "output-driven, input-enabled" hypothesis further develops Swain's output hypothesis and socio-cultural perspective on SLA. This new hypothesis posits that language output is the driving force and the teaching target for SLA while the language input through which the learners acquire both the language form and the content necessary to the output tasks enables the output tasks to be accomplished. In simple terms, this hypothesis aims to combine language learning with language use.

Fourth, this new hypothesis is consistent with our College English teaching reality. Many universities and 
colleges have now reduced the English class hours. If teachers continue to employ traditional teaching methods, students would barely see improvements in their English study in such relatively short periods of time. If they instruct English classes under the new hypothesis, however, students could accomplish many visible and measurable output tasks.

\subsection{Features}

This hypothesis is founded on yet somehow different from Swain's output hypothesis. Wen $(2013,2014,2015)$ agrees on the four functions of the output, namely, noticing/triggering function, hypothesis testing function, meta-linguistic function and fluency function, but also believes that this hypothesis has focuses and challenging objectives different from Swain's.

To start with, this hypothesis is one of second language teaching rather than second language acquisition. Different from the Output Hypothesis which centres on the different functions of both input and output in SLA, this hypothesis is concerned with effective second language teaching for learners of intermediate level and above. In other words, it intends to explore how second language teaching can better serve students' future needs.

In addition, unlike Swain's output hypothesis which is proposed to challenge Krashen's input hypothesis, this hypothesis attempts to challenge the widely held English teaching focuses and objectives in mainland China. To start, traditional English teaching focuses on the quantity and quality of the language input, undervaluing the importance of output in language acquisition, whereas English teaching based on "output-driven, input-enabled" hypothesis puts emphasis on language output, which is believed to not only help students export their language input, but build their interest in absorbing new linguistic knowledge as well. In addition, traditional teaching incorporates language skills of listening, speaking, reading, writing as well as translating into our teaching objectives, which are impossible tasks taking into account the current English teaching reality. This new hypothesis, however, reorients our English teaching. By putting those output language skills as our teaching objectives and allowing the students to choose the one(s) they want to develop, we are more likely to turn out a group of students who can give full play of their talents in language (Wen, 2012).

In all, this new hypothesis has advantages over traditional teaching ideology since it can not only stimulate students' desire to acquire new knowledge but also activate their prior knowledge. This new hypothesis is feasible and will benefit a great many of EFL learners if teachers could keep a good balance between language input and language output and meanwhile conduct well-designed English classes in regard to the four aspects of class instruction--teaching objectives, teaching materials, teaching organization and assessment.

\section{College English Writing Instruction: A New Model}

\subsection{College English Writing Instruction in Mainland China}

At present, our college English writing instruction has encountered some major problems. To begin with, English class hours have been reduced by $1 / 4,1 / 3$ or even $1 / 2$. As a consequence of this, how to make the best of the available class hours to instruct the students to learn English and English writing in particular has become a big challenge for most EFL teachers.

In addition, English writing is supposed to be taught in intensive reading classes since no compulsory English writing courses are offered to non-English majors in some universities in mainland China. Due to the tight course arrangement and the large amount of reading material to be taught, however, teachers may not spare enough time for writing activities, which makes it impossible to effectively conduct writing instruction in class.

Furthermore, the serious flaw in our assessment mechanism distracts the students' attention from exploiting knowledge for the sake of knowledge itself. To be specifically, our college English teaching relies heavily on tests of which multiple-choice items account for a major part in evaluating a student's performance. Under this evaluation system, many students are eager for quick success, unwilling to put more energy or time to improve their English and English writing in particular. Such an evaluation mechanism is detrimental to the cultivation of the students' writing abilities.

To make things worse, many teachers do not attach great importance to college English writing. Some of them seldom teach English writing in class because of the tight teaching schedule. Others are reluctant to teach students how to write in English because it requires a lot of commitment while the result may not turn out to be fruitful. Still others are at a loss for the effective ways to help improve the students' writing and hence choose not to touch upon writing in their English instruction.

These factors, and together with many others, contribute to our English writing instruction reality, in which teachers are consciously or subconsciously diminishing the students' motivation to improve writing skills and do 
disservice to improve their students' writing abilities.

\subsection{A New Teaching model for College English Writing Instruction}

College English teaching has focused on reading in most universities for long. An immediate consequence of this is that many students develop into very competent readers without developing their writing abilities to the same degree. Taking into consideration the college English teaching reality that writing is supposed to be taught in intensive reading class, we might as well teach writing based on reading so that students could take advantage of the available reading materials to improve their writing.

\subsubsection{Teaching Writing Based on Reading}

There are two important differences between reading and writing: deliberateness and focus of reflection (Grabe, 2001). Reading requires more automaticity of sub-processes whereas writing requires more deliberate awareness. While the main goal of reading is to reflect on meaning, reflecting on language is very important in writing to make sure that ideas are expressed appropriately (Yoshimura, 2009). Reading does not always translate into writing abilities.

Despite the differences, it has been acknowledged that reading plays an important role in developing writing ability. Reading gives the writer the 'feel' for the look and texture of reader-based prose (Krashen, 1984). Reading is the basis of writing in academic settings (Carson \& Leki, 1993, p. 1). The information acquired through reading contains not only print-encoded messages but also clues about how the grammatical, lexical, semantic, pragmatic, and rhetorical constitutes combine to make the message meaningful (Ferris \& Hedgcock, 2005, p. 31). Reading supports writing through 'meaningful input' (Hirvela, 2004), which refers to not only facts but specific components that constitute writing, but also the way writers think through the problems they are addressing (Bolch \& Chi, 1995). According to Hirvela (2004), reading and writing abilities share various constructs such as rhetorical structure, linguistic features of writing, lexical and stylistic characteristics of writing (p. 115). Tierney and Shanahan's study (1991) suggests that there is $25 \%$ to $50 \%$ overlap between reading and writing abilities. Teaching reading based on writing has theoretical basis.

\subsubsection{Teaching Writing Based on Reading under the Hypothesis of "Output-driven, input-enabled" Hypothesis}

Teaching writing based on reading is a feasible practice under "output-driven, input-enabled" hypothesis. Reading provides the students with the meaningful language input, which includes not only the linguistic constitutes but also the way the authors organize their ideas. Students could make the best of the meaningful input, mining the elements that might be of great help for them to complete the writing tasks. To connect writing with reading, teaching content, teaching organization as well as evaluation system have to be geared to an effective college English writing instruction.

In respect of teaching content, three factors have to be taken into account. First, the reading materials selected by the instructors should be capable of providing the language learners with the appropriate language form and content to ensure the accomplishment of the writing tasks. Since it seems impossible to expect one input material to fulfil the task of the completion of output tasks, teachers are more likely to provide learners with different kinds of reading materials from which the proper parts are selected for language learning.

Second, the writing tasks could be the ones that language learners hold interest in. In that case, they would feel motivated to complete them and therefore are more willing to get involved in learning the reading materials, which would not only activate their prior knowledge, but also promote them to gain new knowledge. To achieve this goal, teachers have to spend much time selecting the teaching materials that could serve this purpose, or teachers and language learners could work together to seek the teaching materials since students themselves have clearer ideas of what appeals to them.

In terms of teaching organization, several requirements have to be met. To start, the writing lesson should follow proper sequence. Second, class time should be arranged reasonably so that students could make the best of the available time and get fully engaged in the class activities. Third, writing activities should be well organized and assessment on the students' performance must be made. Finally, the writing assignments have to be presented in a clear manner and be the ones within the language learners' ability.

As regards the evaluation system, both language learners' in-class performance and their writing products have to be taken into consideration.

Above all, teachers have to play a leading role. They should not only provide with the students the necessary reading materials but also lead the students to select and use the materials to ensure the completion of the writing tasks. First of all, language instructors can select from those input materials those contributing to the writing 
tasks and design some questions for reading relevant English texts. Besides, instructors could design writing tasks according to themes so that students can accumulate adequate knowledge on certain themes, and more importantly, improve their capabilities to complete writing tasks after gaining the necessary input. In designing writing tasks, teachers should come up with specific ones as well as an overall plan, so that teachers have a clear clue as to where to go and arrange their class time reasonably.

Suppose language learners are asked to introduce their experience of learning a foreign language to their foreign classmates. After clarifying the writing task, teachers may present to the students the following paragraph about a person's English language learning experience in junior middle school and put forward some questions to guide students' reading so that they could get a clue how to organize their ideas in order to successfully introduce to others their past experiences.

My experience with learning a foreign language began in junior middle school, when I took my first English class. I had a kind and patient teacher who often praised all of the students. Because of this positive method, I eagerly answered all the questions I could, never worrying much about making mistakes. I was at the top of my class for two years. (Extracted from New Horizon College English, unit one, book one)

Question 1: What sentence structure to be used to introduce your English learning experience?

Question 2: How possibly to describe your English studies, the teacher and his teaching method?

Question 3: How to organize ideas?

By putting forth the three questions, teachers draw students' attention to these grammatical, lexical and structural constituents of

- the sentence structure of "my experience with...began in... when..."

- detailed description of things, persons using words like "kind", "patient", "positive" rather than those indicating abstract notions like "good";

- the writing model of "topic sentence+ supporting details + conclusion";

- cause-and-effect paragraph writing.

Having introduced to the language learners the necessary language input, instructors may lead the students to make the best of the language input in making up their past experiences by utilizing

- the sentence structure of "my experience with...began in... when..." to introduce their experience of doing things;

- the writing skills of description by means of using words indicating concrete meanings instead of words referring to abstract notions;

- the paragraph building skill of starting a paragraph with topic sentence, providing details to support the topic sentence and ending with conclusion;

- the causal paragraph building skill.

\section{Conclusion}

College English writing is an essential element in EFL acquisition. As a receptive skill, it can not only help language learners internalize their linguistic knowledge, but also enhance their comprehensive language abilities. How to improve language learners' writing performance, therefore, well deserves our attention and effort. "Output-driven, input-enabled" hypothesis which places emphasis on the important role that language output plays in second language acquisition seems to provide an alternative to the teaching of college English writing for non-English majors at tertiary level in mainland China.

Taking into consideration the teaching reality that independent writing course is not offered to non-English majors during their first two years in universities and colleges and that writing is supposed to be taught in reading classes, we may conduct college English writing instruction by combining writing with reading since teaching writing based on reading is theoretically well founded.

To combine writing with reading on the basis of the output-driven, input-enabled hypothesis, instructors have to make adjustments in our teaching objectives, teaching content, teaching organization and evaluation mechanism, in the hope that the writing tasks can meet students' psychological needs and our social needs. In conducting writing instruction, teachers have to play leading roles. Apart from selecting appropriate input materials and assigning proper writing tasks, they are supposed to supervise the language learners to move toward the well-planned teaching objectives step by step through well-designed teaching activities such that writing classes 
can benefit the great majority of the EFL learners.

In the studies that follow, English writing class instruction under the "output-driven, input-enabled" hypothesis will be introduced in detail. Furthermore, teaching experiments will be conducted in an effort to learn to what degree this seemingly effective approach could contribute to our English writing instruction.

\section{Acknowledgement}

This work is sponsored by "the Fundamental Research Funds for the Central Universities" (Grant \#2015MS70).

\section{References}

Bolch, J., \& Chi, L. (1995). A comparison of the use of citations in Chinese and English discourse. In D. Belcher, \& G. Braine (Eds.), Academic Writing in a Second Language: Essays on Research and Pedagogy (pp. 231-274). Norwood, NJ: Ablex.

Cai, L. Z. (2001). Application of task-based approach in college English writing teaching. Foreign Language World, 4, 41-46.

Carson, J., \& Leki, I. (1993). Reading in the Composition Classroom: Second Language Perspective. Boston: Heinle \& Heinle.

Chen, L. P. (2001). On the functions of models in English composition instruction discussed in the light of reading-writing relationships. Foreign Languages and Their Teaching, 4, 28-30.

Chen, W. K. (2010). The reform of the teaching of writing for English majors based on the "output--driven hypothesis". Journal of Henan Institute of Education: Philosophy and Social Sciences, 29(3), 120-122.

Fang, F., \& Xia, B. J. (2010). Construction of competence-based, output-driven English course group. Shandong Foreign Language Teaching Journal, 3, 3-8.

Fang, L. L. (2004). The length approach writing instruction in college English classes. Foreign Language World, $3,40-45$.

Ferris, D. R., \& Hedgcock, J. S. (2005). Teaching ESL Composition: Purpose, Process, and Practice. Mahwah, NJ: Lawrence Erlbaum Associates.

Grabe, W. (2001). Reading-writing relations: Theoretical perspectives and instructional practices. In D. Belcher, \& A. Hirvela (Eds.), Linking Literacies: Perspectives on L2 Reading-Writing Connections (pp. 15-47). Ann Arbor MI: The University of Michigan Press.

Guo, X. Y. (2009). Use blogs to improve teaching of College English writing. Modern Foreign Languages, 32(3), 314-321, 330.

Guo, Y. (2011). An empirical study on the effect of the length approach on Chinese non-English major's English writing anxiety and writing ability. Foreign Language World, 2, 73-82.

Han, J. L. (2001). Teaching writing: A process genre approach. Foreign Language World, 4, 35-40.

Hirvela, A. (2004). Connecting Reading \& Writing in Second Language Writing Instruction. Ann Arbor MI: The University of Michigan Press. https://doi.org/10.3998/mpub.23736

Krashen, S. (1984). Writing: Research, Theory, and Applications. Oxford, UK: Pergamon.

Krashen S.(1984). The Input Hypothesis: Issues and Implications. London: Longman.

Li, F. X. (1997).Teaching writing in an intensive reading course. Foreign Language World, 2, 52-56.

Liu, B., Ge, L. L., \& Li, G. W. (2012). An empirical study on the corpus-based teaching model of College English writing. Foreign Language and Literature, 28(4), 131-135.

Liu, J. R., Zhang, H., \& Wang, N. (2014). An empirical study on writing competence of Chinese college EFL Learners --Based on information and technology assisted teaching. E-education Research, 5, 82-87.

Ni, Q. Q.(2009). The development of student writing ability via collaborative-learning-based writing in a computer/web environment. Computer-assisted Foreign Language Education, 5, 63-68.

Shi, X. L. (2001). Multimedia computer and English writing teaching reform. Foreign Language World, 6, $22-25$.

Swain, M. (1985). Communicative competence: Some roles of comprehensible input and comprehensible output in its development. In S. Gass, \& C. Madden (Eds.), Input in Second Language Acquisition (pp. 235-253). Rowley, MA: Newbury House. 
Swain, M. (1995). Three functions of output in second language learning. In Cook, G. Cook, \& B. Seidlhofer (Eds.), Principle and Practice in Applied Linguistics. Oxford, England: Oxford University Press.

Swain, M., \& Lapkin, S. (1995). Problems in output and the cognitive processes they generate: A step towards second language learning. Applied Linguistics, 16, 371-391. https://doi.org/10.1093/applin/16.3.371

Tierney, R. J., \& Shanahan, T. (1991). Research on the reading-writing relationship: Interactions, transactions, and outcomes. In R. Barr, M. L. Kamil, P. B. Mosenthal, \& P. D. Pearson (Eds.), Handbook of Reading Research, 2, 246-280. New York: Longman.

Wang, C. M., Niu, R. Y., \& Zheng, X. X. (2000). Improving English through writing. Foreign Language Teaching and Research, 32(3), 207-212.

Wang, H. L., \& Gao, G. Z. (2001). Some comments of foreign experts on the role of e-mail in English writing. Foreign Languages and Their Teaching, 5, 44-45.

Wang, J. P. (2011). Reform and practice of higher vocational business English writing instruction based on the output hypothesis. Education and Vocation, 30, 106-107.

Wang, N. (2014). Innovate English writing teaching, experience digital writing. Foreign Languages in China, 2, 68-74.

Wang, Y. F. (2005). Empirical studies on L2 writing in China: A review. Foreign Languages in China, 2(1), 50-55.

Wen, Q. F. (2005). A critique of length approach. Modern Foreign Languages, 28(3), 308-311.

Wen, Q. F. (2008). On the output-driven hypothesis and reform of English-skill courses for English majors. Foreign Language World, 2, 2-9.

Wen, Q. F. (2012). Characteristics of challenges for College English from the perspective of curriculum theory: Problems and suggested solutions. Foreign Language Teaching and Research, 44(2), 283-292.

Wen, Q. F. (2013). Application of the output-driven hypothesis in college English teaching: Reflections and suggestions. Foreign Language World, 6, 14-22.

Wen, Q. F. (2014). Output-driven, input-enabled hypothesis: A tentative theory of foreign language classroom instruction for university students. Foreign Language Education in China, 7(2), 3-12.

Wen, Q. F. (2015). Developing a theoretical system of production-oriented approach in language teaching. Foreign Language Teaching and Research, 47(4), 547-560.

Wu, F. (2005). Comprehensible output and learning efficiency --An empirical study of the length approach. Foreign Language Education, 26(1), 44-49.

$\mathrm{Wu}$, P. (2001). An experiment of applying input theory to college English teaching. Foreign Language World, 3, 53-56.

Yang, C. P. (1998). Speaking and writing in FLT. Foreign Languages and Their Teaching, 3, 22-25.

Yang, L. P., \& Han, G. (2012). An empirical study of academic writing teaching to undergraduates based on the project-based learning model. Foreign Languages World, 5, 8-16.

Yang, Y. L., \& Dong, Y. Z. (2010). Writing through reading and reading through writing--A new exploration of experiential teaching approach. Foreign Languages in China, 1, 13-21.

Yoshimura, F. (2009). Effects of connecting reading and writing and a checklist to Guide the reading process on EFL learners' learning about English writing. Procedia Social and Behavioral Sciences (Vol. 1, pp. 1871-1883). https://doi.org/10.1016/j.sbspro.2009.01.330

Yu, T. (2010). Writing collaboratively on a Wiki: An empirical study. E-education Research, 3, 78-82.

Zheng, S. T. (2011). New Horizon College English (second edition): Reading and Writing (Book one). Beijing: Foreign Language Teaching and Research Press.

\section{Copyrights}

Copyright for this article is retained by the author(s), with first publication rights granted to the journal.

This is an open-access article distributed under the terms and conditions of the Creative Commons Attribution license (http://creativecommons.org/licenses/by/4.0/). 